\title{
Bathurst Burr (Xanthium spinosum) Powder-A New Natural Effective Adsorbent for Crystal Violet Dye Removal from Synthetic Wastewaters
}

\author{
Giannin Mosoarca (D), Cosmin Vancea *, Simona Popa * and Sorina Boran
}

Faculty of Industrial Chemistry and Environmental Engineering, Politehnica University Timisoara, Bd. V. Parvan, No. 6, 300223 Timisoara, Romania; giannin.mosoarca@upt.ro (G.M.); sorina.boran@upt.ro (S.B.)

* Correspondence: cosmin.vancea@upt.ro (C.V.); simona.popa@upt.ro (S.P.); Tel.: +40-256404194 (C.V.); $+40-256404212$ (S.P.)

Citation: Mosoarca, G.; Vancea, C.; Popa, S.; Boran, S. Bathurst Burr (Xanthium spinosum) Powder-A New Natural Effective Adsorbent for Crystal Violet Dye Removal from Synthetic Wastewaters. Materials 2021, 14, 5861. https://doi.org/10.3390/ ma14195861

Academic Editor: Dimitrios Papoulis

Received: 23 August 2021

Accepted: 5 October 2021

Published: 7 October 2021

Publisher's Note: MDPI stays neutral with regard to jurisdictional claims in published maps and institutional affiliations.

\section{Copyright: (c) 2021 by the authors.} Licensee MDPI, Basel, Switzerland. This article is an open access article distributed under the terms and conditions of the Creative Commons Attribution (CC BY) license (https:// creativecommons.org/licenses/by/ $4.0 /)$.

\begin{abstract}
A new natural adsorbent material, Bathurst burr powder, was used to remove crystal violet dye from synthetic wastewaters. Particle size distribution and SEM and FTIR analyses were performed to characterize it. The effect of the operational adsorption process parameters $(\mathrm{pH}$, ionic strength, initial dye concentration, adsorbent dose, contact time, temperature) onto the adsorption process was evaluated in a batch system. Equilibrium, kinetic, and thermodynamic studies were performed in order to understand the adsorption process. Taguchi method and ANOVA test were used to optimize the dye adsorption conditions and to establish the percentage contribution of each factor, respectively. The accuracy of the Taguchi prediction method was analyzed by correlating the predicted dye removal efficiency with the experimentally determined one. The particle size distribution analysis showed that $82.15 \%$ of the adsorbent particles have an average size below $0.5 \mathrm{~mm}$. The adsorption process followed the Langmuir isotherm and pseudo-second order kinetic model. Maximum adsorption capacity value $\left(164.10 \mathrm{mg} \cdot \mathrm{g}^{-1}\right)$ was higher compared to many similar adsorbents. The process was endothermic, spontaneous, and favorably involving a physisorption mechanism. The Taguchi method showed that the most influential controllable factor was $\mathrm{pH}$ (65\% contribution in adsorption efficiency) and the data analysis indicates a very good accuracy of the experimental design $\left(R^{2}=0.994\right)$. The obtained results demonstrated that Bathurst burr powder can be used as a cheap and efficient adsorbent for crystal violet dye removal from aqueous solution.
\end{abstract}

Keywords: natural adsorbent; crystal violet; adsorption; isotherm; kinetic; Taguchi method

\section{Introduction}

Crystal violet is a cationic dye used as a textile colorant, paper dye, biological stain, and as veterinary animal drug. It has high toxicity and can cause digestive tract irritation, kidney failure, and cancer [1-5]. Its presence in the aquatic environment, even in low concentrations, leads to plants photosynthesis process disorder. It has high chemical stability, high solubility, and low biodegradability. It is therefore necessary to remove this stain from residual effluents [1-3].

Many methods have been used to remove the cationic dyes (inclusive crystal violet) from wastewater and dye solutions. Coagulation, flocculation, electrocoagulation, ozonation and catalytic ozonation, photochemical and photocatalytic degradation, chemical and electrochemical oxidation, membrane processes (ultrafiltration, reverse osmosis), biodegradation, ion exchange, and adsorption have been mentioned in the literature as being effective for this purpose [1,3-6].

In recent years, the adsorption process has been used more and more often by researchers to achieve the removal of dyes from wastewaters. This is due to the fact that adsorption has many technical and economic advantages such as: high selectivity and 
efficiency, simplicity and flexibility in operation, good applicability, possibility to reuse the adsorbent, and relatively low costs [4-6].

The process becomes extremely cost-effective by using cheap materials that can be found in abundance in nature [7-11]. Several low-cost natural materials have been used for crystal violet dye removal from aqueous solutions: cedar cones [11], Calotropis procera leaf [12], Laminaria japonica [13], rice bran [13], wheat bran [13], coniferous pinus bark powder [14], sugarcane fiber [15], sawdust [15], coir pith [15], peel of Cucumis sativa fruit [16], jackfruit leaf powder [17], pineapple leaf powder [18], papaya seeds [19], breadfruit skin [8], water hyacinth root powder [20], Eragrostis plana nees [7], pará chestnut husk [21], date palm leaves powder [22], corn stalk [23], Ocotea puberula bark powder [5], Moringa oleifera pod husk [24], and almond shells [25].

Bathurst burr (Xanthium spinosum) is an herbaceous plant, up to 1 meter tall, with a richly branched stem and full of thorns. It grows especially in hilly and plain areas and also in low mountainous regions. Originally from South America, it has spread widely in Europe, Australia, parts of Africa, Asia, and North America, and is a very invasive plant. It grows on pastures, roadsides, fences, and abandoned lands and has an extraordinary resistance to drought, pollution, and any aggressive environmental factor. It is used in traditional medicine based on its: decongestant, diuretic, anti-inflammatory, disinfectant, diuretic, antidiabetic, and antitumor properties [26,27]. The seeds of the plant contain carboxyatractyloside, which is poisonous to livestock, but animals usually avoid this plant because of its thorns, which can cause them unpleasant wounds [28,29].

The aim of this research study was to remove crystal violet dye from synthetic wastewaters using the Bathurst burr powder as an adsorbent material. The effect of $\mathrm{pH}$, contact time, adsorbent dose, initial dye concentration, temperature, and ionic strength onto the adsorption process was evaluated in the batch system. In order to understand the adsorption mechanism, different isotherms, kinetics, and thermodynamics studies were performed. The Taguchi method was used for adsorption conditions optimization. In addition, the ANOVA analysis was used to assess the result and to determine the contribution percentage of each parameter on the dye removal process.

\section{Materials and Methods}

In order to obtain the adsorbent material, the aerial part of Bathurst burr mature plants were purchased from the company StefMar (Ramnicu Valcea, Romania) whose activity is the processing and packaging of medicinal and aromatic plants. The plants were washed with distilled water and then first dried at room temperature for 3 days and then in an air oven at $105^{\circ} \mathrm{C}$ for $24 \mathrm{~h}$. After drying, they were electrically grounded. The obtained powder was passed through a $2 \mathrm{~mm}$ sieve.

SEM analysis and FTIR spectroscopy were performed to characterize the adsorbent material using a Quanta FEG 250 (FEI, Eindhoven, The Netherlands) scanning electron microscope (1600× magnitude) and a Shimadzu Prestige-21 FTIR (Shimadzu, Kyoto, Japan) spectrophotometer. Analyses were compared before and after the dye adsorption process.

In batch adsorption experiments, the influence of various factors affecting the process was studied, at a constant stirring intensity provided by a shaker. The $\mathrm{pH}$ was adjusted using $0.1 \mathrm{~N} \mathrm{NaOH}$ and $\mathrm{HCl}$ solutions. The influence of ionic strength was investigated using $\mathrm{NaCl}$ as background electrolyte. The crystal violet concentration was measured with a Specord 200 PLUS UV-VIS (Analytik Jena, Jena, Germany) spectrophotometer at a wavelength of $590 \mathrm{~nm}$. Each test was conducted using three independent replicates.

The crystal violet amounts adsorbed at equilibrium $\left(q_{e}\right)$ and the dye removal percentage $R(\%)$ were calculated with equations (1) and (2) [1,4,7]:

$$
\begin{gathered}
q_{e}=\frac{\left(C_{0}-C_{e}\right) \cdot V}{m}, \\
R(\%)=\frac{\left(C_{0}-C_{e}\right)}{C_{0}} \cdot 100,
\end{gathered}
$$


where: $C_{0}$ is the initial crystal violet concentration $\left(\mathrm{mg} \cdot \mathrm{L}^{-1}\right), C_{e}$ is the crystal violet equilibrium concentration (mg. $\left.\mathrm{L}^{-1}\right), V$ is the solution volume $(\mathrm{L})$, and $m$ is the mass of adsorbent (g).

The optimum conditions for crystal violet adsorption were established using Taguchi (L27) experimental design. To achieve this goal, the effect of six factors (at three levels) on dye removal efficiency was followed. These controllable factors and their levels are detailed in Table 1. For the experimental design, the Taguchi method uses an orthogonal matrix $(\mathrm{OA})$ evaluating the signal/noise ratio $(\mathrm{S} / \mathrm{N})$ using the "larger is the better" option [30-32]. In order to evaluate the results of the Taguchi method and to establish the percentage contribution of each factor to the efficiency of crystal violet removal, an analysis of variance (ANOVA) was realized [30,32]. The necessary calculations were performed with the Minitab 19 Software (version 19.1.1, Minitab LLC, State College, PA, USA).

Table 1. Controllable factors and their levels.

\begin{tabular}{cccc}
\hline Factor & Level 1 & Level 2 & Level 3 \\
\hline $\mathrm{pH}$ & 2 & 6 & 12 \\
Time $(\mathrm{min})$ & 5 & 20 & 40 \\
Adsorbent dose $\left(\mathrm{mg} \cdot \mathrm{L}^{-1}\right)$ & 0.5 & 2.0 & 3.0 \\
Initial dye concentration $\left(\mathrm{mg} \cdot \mathrm{L}^{-1}\right)$ & 50 & 150 & 250 \\
Temperature $(\mathrm{K})$ & 285 & 294 & 311 \\
Ionic strength $\left(\mathrm{mol} \mathrm{L}^{-1}\right)$ & 0 & 0.10 & 0.25 \\
\hline
\end{tabular}

The desorption study was realized in batch mode, at constant stirring for $2 \mathrm{~h}$, using different desorbing agents (distilled water, $0.1 \mathrm{M} \mathrm{HCl}$, and $0.1 \mathrm{M} \mathrm{NaOH}$ ).

\section{Results and Discussion}

\subsection{Adsorbent Characterization}

The particle size distribution analysis of the Bathurst burr powder (Supplementary Material, Figure S1) shows that $82.15 \%$ of the particles have an average size bellow $0.5 \mathrm{~mm}$ and $50 \%$ of them are smaller than $0.348 \mathrm{~mm}$.

Figure 1 shows the morphology of the adsorbent before and after adsorption. Before adsorption, the surface had many pores that provided a large adsorption surface and a large number of sites available for retaining dye molecules (Figure 1a). After adsorption, the surface of the adsorbent was saturated and covered with crystal violet molecules, which filled the pores and cavities during the process (Figure 1b).
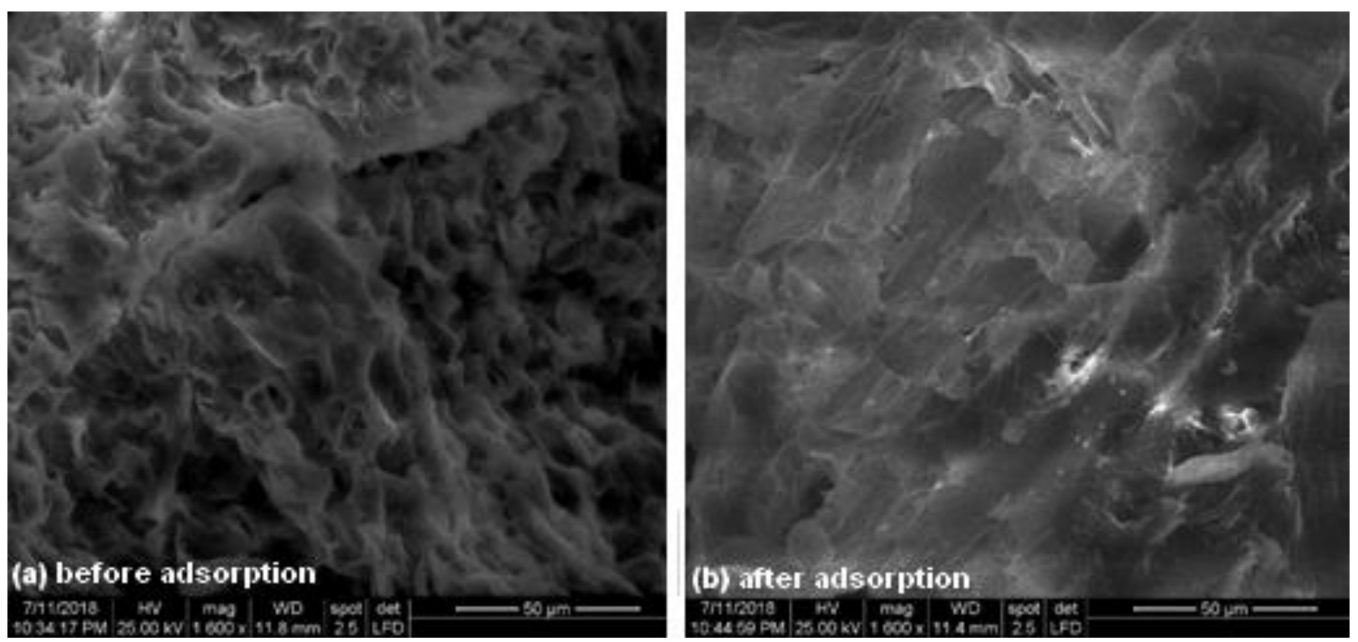

Figure 1. SEM image of adsorbent surface before (a) and after (b) crystal violet adsorption [adsorption conditions: $\mathrm{pH} 7$; initial dye concentration: $100 \mathrm{mg} \cdot \mathrm{L}^{-1}$; contact time: $30 \mathrm{~min}$; adsorbent dose: $2 \mathrm{~g} \cdot \mathrm{L}^{-1}$; temperature: $294 \mathrm{~K}$, ionic strength: $0 \mathrm{~mol} \mathrm{~L}^{-1}$ ]. 
The FTIR spectra of adsorbent before and after adsorption (Figure 2) indicate different bands specific for main functional group existing in cellulose $\left(3448 \mathrm{~cm}^{-1}, 2340 \mathrm{~cm}^{-1}, 1630 \mathrm{~cm}^{-1}\right.$, $1368 \mathrm{~cm}^{-1}$, and $\left.1000 \mathrm{~cm}^{-1}\right)$ [33-37] and hemicellulose $\left(3448 \mathrm{~cm}^{-1}, 1368 \mathrm{~cm}^{-1}\right)$ [36,38-40]. These assignments are shown in Table 2. After adsorption, the appearance or disappearance of any band was not found. It only presents small changes of the wavenumber, suggesting that the physical interaction or ion exchange can intervene in the adsorption mechanism [41].

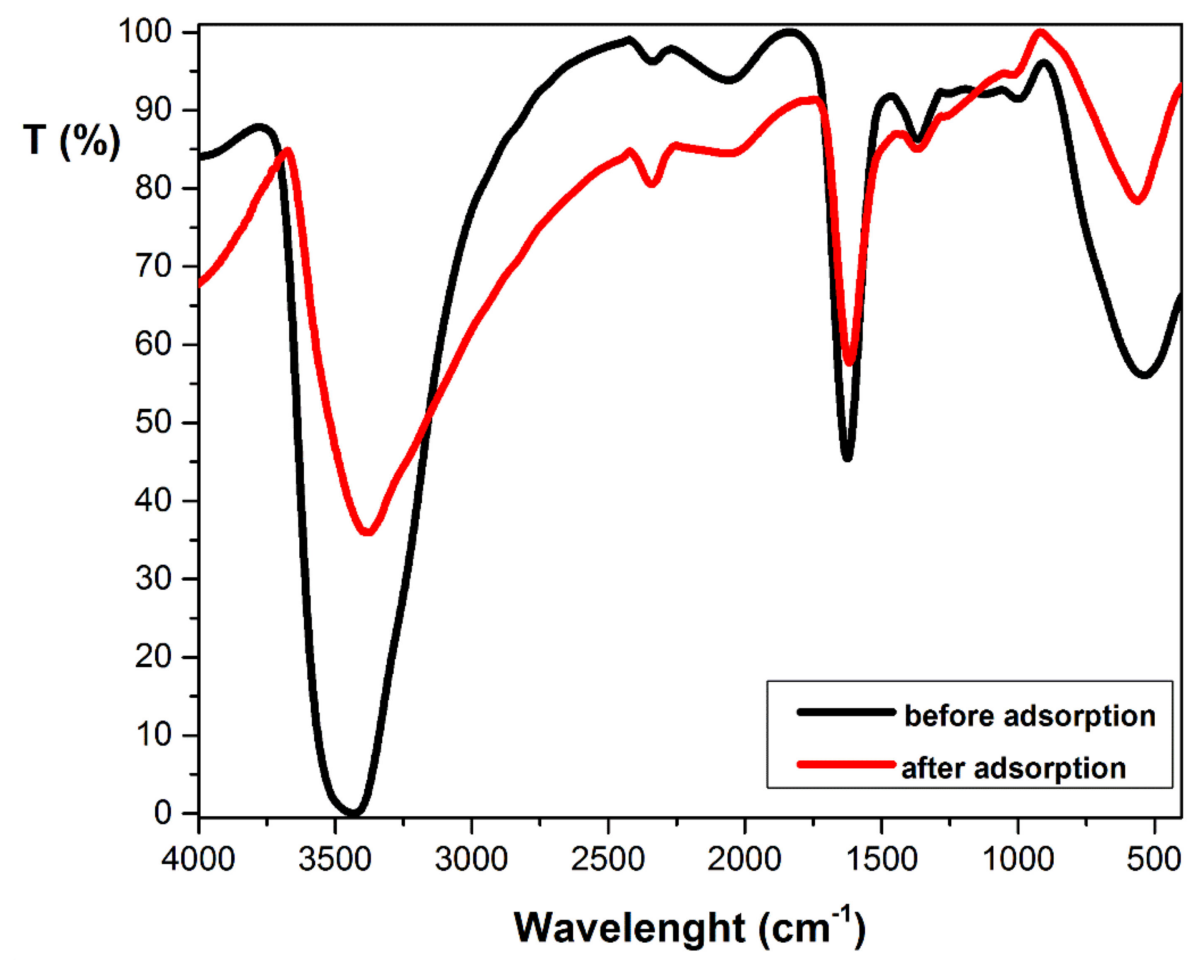

Figure 2. FTIR spectrum of Bathurst burr powder before and after crystal violet adsorption. [adsorption conditions: $\mathrm{pH} 7$; initial dye concentration: $100 \mathrm{mg} \cdot \mathrm{L}^{-1}$; contact time: $30 \mathrm{~min}$; adsorbent dose: $2 \mathrm{~g} \cdot \mathrm{L}^{-1}$; temperature: $294 \mathrm{~K}$, ionic strength: $0 \mathrm{~mol} \mathrm{~L}^{-1}$ ].

Table 2. The FTIR bands that were assigned to different cellulose and hemicellulose.

\begin{tabular}{ccc}
\hline FTIR Bands & Assignment & Reference \\
\hline $3448 \mathrm{~cm}^{-1}$ & O-H stretching & {$[31,36,38]$} \\
$2340 \mathrm{~cm}^{-1}$ & O-H bending of adsorbed water & {$[32]$} \\
$1630 \mathrm{~cm}^{-1}$ & O-H bending of adsorbed water & {$[33]$} \\
$1368 \mathrm{~cm}^{-1}$ & C-H bending & {$[34,36,37]$} \\
$1000 \mathrm{~cm}^{-1}$ & C-O stretching & {$[35]$} \\
\hline
\end{tabular}

\subsection{Effect of $\mathrm{pH}$ and Ionic Strength on Crystal Violet Adsorption}

$\mathrm{pH}$ is an important parameter that affects the adsorbent surface charge [42]. The influence of this parameter on the adsorption capacity was followed in the $\mathrm{pH}$ range 2-12 (Figure 3a). The adsorption capacity increases with $\mathrm{pH}$, reaching the highest values at basic conditions. A similar phenomenon was observed in other similar studies regarding the adsorption of crystal violet on low-cost adsorbents $[8,9,43,44]$. The adsorbent materials have different functional groups on the surface. At lower $\mathrm{pH}$ these groups will be protonated and the charge on the adsorbent surface will be predominantly positive, therefore, the adsorption process will be more difficult due to electrostatic repulsion with cationic dye molecules. For higher $\mathrm{pH}$ values, these functional groups will be deprotonated and the charge on the adsorbent surface will be predominantly negative. This phenomenon favors the adsorption process because there is a strong electrostatic attraction between negatively 
charged adsorbent surface and the dye cations $[18,22,45]$. The adsorption capacity on the $\mathrm{pH}$ range 8-12 remains practically constant, suggesting that other mechanisms besides electrostatic attraction may be involved in the adsorption process $[46,47]$.
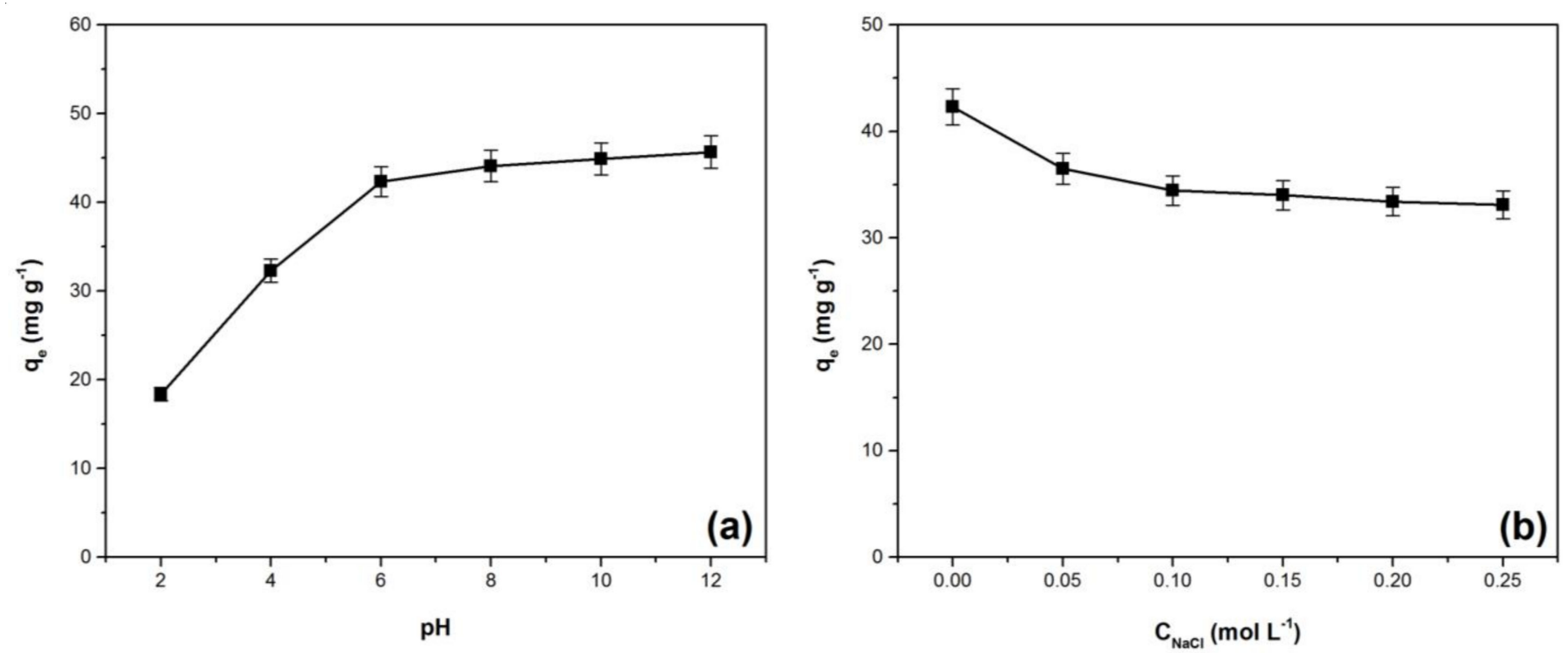

Figure 3. Effect of $\mathrm{pH}(\mathbf{a})$ and ionic strength (b) on adsorption capacity for the crystal violet adsorption onto Bathurst burr powder [adsorption conditions: (a): initial dye concentration: $100 \mathrm{mg} \cdot \mathrm{L}^{-1}$; contact time: $30 \mathrm{~min}$; adsorbent dose: $2 \mathrm{~g} \cdot \mathrm{L}^{-1}$; temperature: $294 \mathrm{~K}$, ionic strength: $0 \mathrm{~mol} \mathrm{~L}-1$ (b): $\mathrm{pH} 7$, initial dye concentration: $100 \mathrm{mg} \cdot \mathrm{L}^{-1}$; contact time: $30 \mathrm{~min}$; adsorbent dose: $2 \mathrm{~g} \cdot \mathrm{L}^{-1}$; temperature: $294 \mathrm{~K}$ ].

Another important factor that can influence the adsorption process is the ionic strength. The effect of this factor on the adsorption capacity is presented in Figure 3b. The decrease of adsorption capacity as the ionic strength increases is based on the competitive effect between the dye and sodium ions in occupying the available adsorption sites on the adsorbent surface $[45,46]$. A similar influence of ionic strength on the crystal violet adsorption process has been reported in other previous scientific articles $[43,48,49]$.

\subsection{Effect of Adsorbent Dose and Initial Dye Concentration on Crystal Violet Adsorption}

Figure 4a illustrates the adsorbent dose effect on the crystal violet adsorption process. The increase of adsorbent amount has a positive effect on the dye removal efficiency and a negative effect on the adsorption capacity. A similar phenomenon has been reported for this dye adsorbed using: eggshells [4], Ocotea puberula bark powder [5], pinus bark powder [14], lemongrass leaf combined with cellulose acetate [42], functionalized multi-walled carbon nanotubes [50], and inactive biomass of Diaporthe schini [51]. The increase of the adsorbent material dose leads to an increase of adsorption surface; therefore, removal efficiency of the dye will be higher $[11,14,18,50]$. The reported decrease of the adsorption capacity $\left(\mathrm{q}_{\mathrm{e}}\right)$ can be explained based on the assumption that even if the adsorption sites number increases, many of them remain unsaturated. Other phenomenon such as agglomeration of adsorbent material particles may also occur $[4,23,50,51]$.

The adsorption capacity increases and the removal efficiency decreases as initial dye concentration increases, as shown in Figure $4 \mathrm{~b}$. Similar effects were mentioned for other adsorbents used to retain crystal violet: eggshells [4], Ananas comosus (pineapple) leaf powder [18], and corn stalk [23]. The increase of the adsorption capacity can be attributed to the fact that a high initial dye concentration leads to an increase of the concentration gradient between the dye solution and the adsorbent surface, leading to an increase of the driving force that favors the external mass transfer $[4,11,18,51,52]$. At the same time, the number of collisions between dye molecules and adsorbent particles material are favored, intensifying adsorption [53]. The unfavorable effect of increasing initial dye concentration 
upon removal efficiency derives from the fact that the active adsorption sites become saturated with the dye molecules accumulated during the process $[4,18,50,54]$.
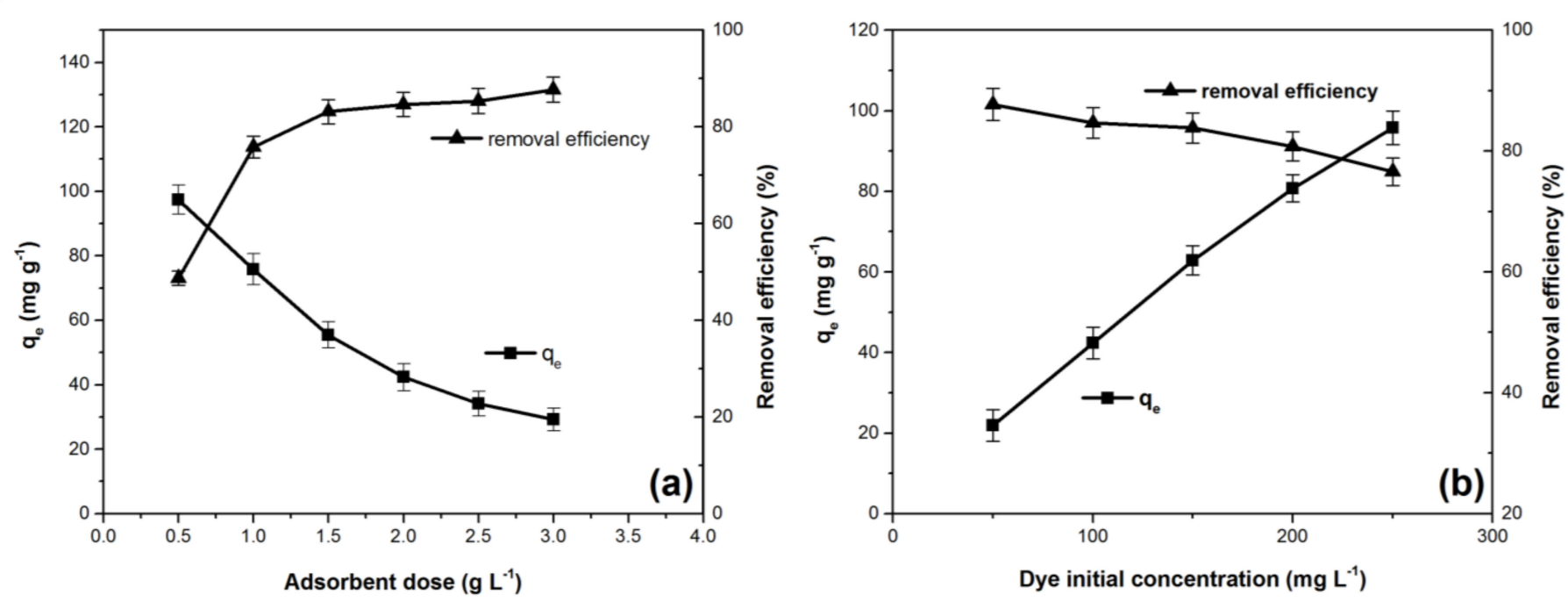

Figure 4. Effect of adsorbent dose (a) and initial dye concentration (b) on adsorption capacity and removal efficiency for the crystal violet adsorption onto Bathurst burr powder [adsorption conditions: (a): $\mathrm{pH}$ 7; initial dye concentration: $100 \mathrm{mg} \cdot \mathrm{L}^{-1}$; contact time: $30 \mathrm{~min}$; temperature: $294 \mathrm{~K}$, ionic strength: $0 \mathrm{~mol} \mathrm{~L}^{-1}(\mathbf{b}): \mathrm{pH}$ 7, contact time: $30 \mathrm{~min}$; adsorbent dose: $2 \mathrm{~g} \cdot \mathrm{L}^{-1}$; temperature: $294 \mathrm{~K}$; ionic strength: $0 \mathrm{~mol} \mathrm{~L}^{-1}$ ].

\subsection{Equilibrum Study}

Adsorption isotherms are used to describe the interactions between adsorbate and adsorbent that take place in the process. The calculated parameters using these isotherms provide information about the properties and affinities of the adsorbent material surface as well as about the adsorption mechanism [1,11,52].

Based on the data presented in Figure $4 \mathrm{~b}$ (experimental results and working conditions), Langmuir and Freundlich isotherms, in the form of non-linear equations [7,8,43,55-57], were used for this purpose:

$$
\begin{aligned}
& \text { Langmuirisothermnon - linearequation }: q_{e}=\frac{q_{m} \cdot K_{L} \cdot C_{e}}{1+K_{L} \cdot C_{e}}, \\
& \text { Freundlichisothermnon - linearequation }: q_{e}=K_{F} \cdot C_{e}^{1 / n_{F}},
\end{aligned}
$$

where: $q_{m}$ is the maximum absorption capacity $\left(\mathrm{mg} \cdot \mathrm{g}^{-1}\right), K_{L}$ and $K_{F}$ are the Langmuir and Freundlich constants, respectively, and $1 / n_{F}$ is an empirical constant indicating the intensity of adsorption.

Both isotherms curves for crystal violet adsorption are presented in the Supplementary Material, Figure S2.

In order to establish the best equations that describe the adsorption process, values of determination coefficient $\left(\mathrm{R}^{2}\right)$, sum of square error (SSE), chi-square $\left(\chi^{2}\right)$ and average relative error (ARE) were considered [57]. The criterion for their applicability was the higher value for $R^{2}$ and the lower values for $S S E, \chi^{2}$, and ARE. These parameters were determined with equations (5) - (8) [57].

$$
R^{2}=1-\frac{\sum_{i=1}^{n}\left(y_{i, \exp }-y_{i, m o d}\right)^{2}}{\sum_{i=1}^{n}\left(y_{i, e x p}-\overline{y_{i, e x p}}\right)^{2}},
$$




$$
\begin{gathered}
S S E=\sum_{i=1}^{n}\left(y_{i, \exp }-y_{i, \text { mod }}\right)^{2}, \\
\chi^{2}=\sum_{i=1}^{n} \frac{\left(y_{i, \exp }-y_{i, \text { mod }}\right)^{2}}{y_{i, \text { mod }}}, \\
A R E=\frac{100}{n} \sum_{i=1}^{n}\left|\frac{y_{i, \exp }-y_{i, \bmod }}{y_{i, \bmod }}\right|,
\end{gathered}
$$

where: $y_{i, \exp }$ is the experimental value, $y_{i, \bmod }$ is the modeled value, $\overline{y_{i, \exp }}$ is the mean values, and $n$ is the total amount of information.

The values of $\left(\mathrm{R}^{2}\right),(\mathrm{SSE}),\left(\chi^{2}\right)$ and (ARE) are summarized in Table 3. It can be concluded that Langmuir isotherm best describes the adsorption process.

Table 3. Adsorption isotherms model constants and the corresponding error functions.

\begin{tabular}{ccc}
\hline Isotherm Model & Parameters & Value \\
\hline & $\mathrm{K}_{\mathrm{L}}\left(\mathrm{L} \mathrm{mg}^{-1}\right)$ & $0.024 \pm 0.001$ \\
& $\mathrm{q}_{\max }\left(\mathrm{mg}^{-1}\right)$ & $164.1 \pm 4.23$ \\
Langmuir non-linear & $\mathrm{R}^{2}$ & 0.9967 \\
& $\chi^{2}$ & 0.222 \\
& $\mathrm{SSE}$ & 11.47 \\
& $\mathrm{ARE}(\%)$ & 2.57 \\
\hline \multirow{2}{*}{ Freundlich non-linear } & $\mathrm{K}_{\mathrm{f}}\left(\mathrm{mg} \cdot \mathrm{g}^{-1}\right)$ & $8.62 \pm 1.47$ \\
& $1 / \mathrm{n}$ & $0.60 \pm 0.03$ \\
& $\mathrm{R}^{2}$ & 0.9828 \\
& $\chi^{2}$ & 1.249 \\
& $\mathrm{SSE}$ & 62.12 \\
& $\mathrm{ARE}(\%)$ & 6.94 \\
\hline
\end{tabular}

The $R_{L}$ separation coefficient can be used to predict whether an adsorption system is favorable or unfavorable. It can be calculated using the following equation:

$$
R_{L}=\frac{1}{1+K_{L} \cdot C_{0}}
$$

where: $K_{L}$ is the Langmuir constant, and $C_{0}$ is the initial dye concentration $\left(\mathrm{mg} \cdot \mathrm{L}^{-1}\right)[10,11,22]$.

The calculated value for $R_{L}(0.29)$ indicates a favorable adsorption.

The value of the maximum adsorption capacity obtained for Bathurst burr powder, $164.10\left(\mathrm{mg} \cdot \mathrm{g}^{-1}\right)$, is higher than other similar adsorbents previously reported in the literature. Table 4 shows the values for the maximum adsorption capacities of several similar

\begin{tabular}{|c|c|c|}
\hline Adsorbent & $\begin{array}{c}\text { Maximum Adsorption } \\
\text { Capacity }\left(\mathrm{mg} \cdot \mathrm{g}^{-1}\right)\end{array}$ & Reference \\
\hline Water hyacinth root powder & 322.58 & [20] \\
\hline Used black tea leaves & 200.00 & [58] \\
\hline Bathurst burr powder & 164.10 & This study \\
\hline Moringa oleifera pod husk & 156.25 & [24] \\
\hline Breadfruit skin & 145.80 & [8] \\
\hline Papaya seeds & 85.99 & [19] \\
\hline Pará chestnut husk & 83.60 & [21] \\
\hline Pineapple leaf powder & 78.22 & [18] \\
\hline
\end{tabular}
adsorbents used for the adsorption of crystal violet dye.

Table 4. Maximum adsorption capacities values of similar adsorbents used for the crystal violet dye adsorption. 
Table 4. Cont.

\begin{tabular}{ccc}
\hline Adsorbent & $\begin{array}{c}\text { Maximum Adsorption } \\
\text { Capacity } \mathbf{( m g} \cdot \mathbf{g}^{-\mathbf{1})}\end{array}$ & Reference \\
\hline Wheat bran & 69.15 & {$[13]$} \\
Laminaria japonica & 66.64 & {$[13]$} \\
Coir pith & 65.53 & {$[15]$} \\
Eragrostis plana nees & 60.10 & {$[7]$} \\
Jackfruit leaf powder & 43.39 & {$[17]$} \\
Rice bran & 41.68 & {$[13]$} \\
Sawdust & 37.83 & {$[15]$} \\
Date palm leaves powder & 37.73 & {$[22]$} \\
Peel of Cucumis sativa fruit & 34.24 & {$[16]$} \\
Coniferous pinus bark powder & 32.78 & {$[11]$} \\
Cedar cones & 13.64 & {$[25]$} \\
Almond shells & 12.20 & {$[15]$} \\
Sugarcane fiber & 10.44 & {$[23]$} \\
Corn stalk & 9.64 & {$[12]$} \\
\hline
\end{tabular}

\subsection{Kinetic and Thermodynamic Studies}

The adsorption kinetics study provides information on the operating conditions and the kinetic parameters. These are the basis for predicting the adsorption rate and designing the adsorption processes [52,59].

The effect of contact time on crystal violet adsorption is shown in Figure 5a. The adsorption capacity increases with the contact time between the dye solution and the adsorbent material. After $30 \mathrm{~min}$, the equilibrium is reached and the value of this parameter remains practically constant. In the first $15 \mathrm{~min}$ the increase is more pronounced because at the beginning of the process many free adsorption sites on the surface of the adsorbent are available to retain the dye, $[8,9,24,42,49]$. After $15 \mathrm{~min}$ the adsorption capacity increases more slowly, because more and more free sites on the adsorbent surface are occupied by dye molecules and repulsive forces between adsorbed and liquid phase molecules may occur $[8,9,45,50]$. The increase of the adsorption capacity stops when the equilibrium is reached, the whole adsorbent surface becomes saturated with dye, and the adsorption sites are all occupied $[8,9,47]$.
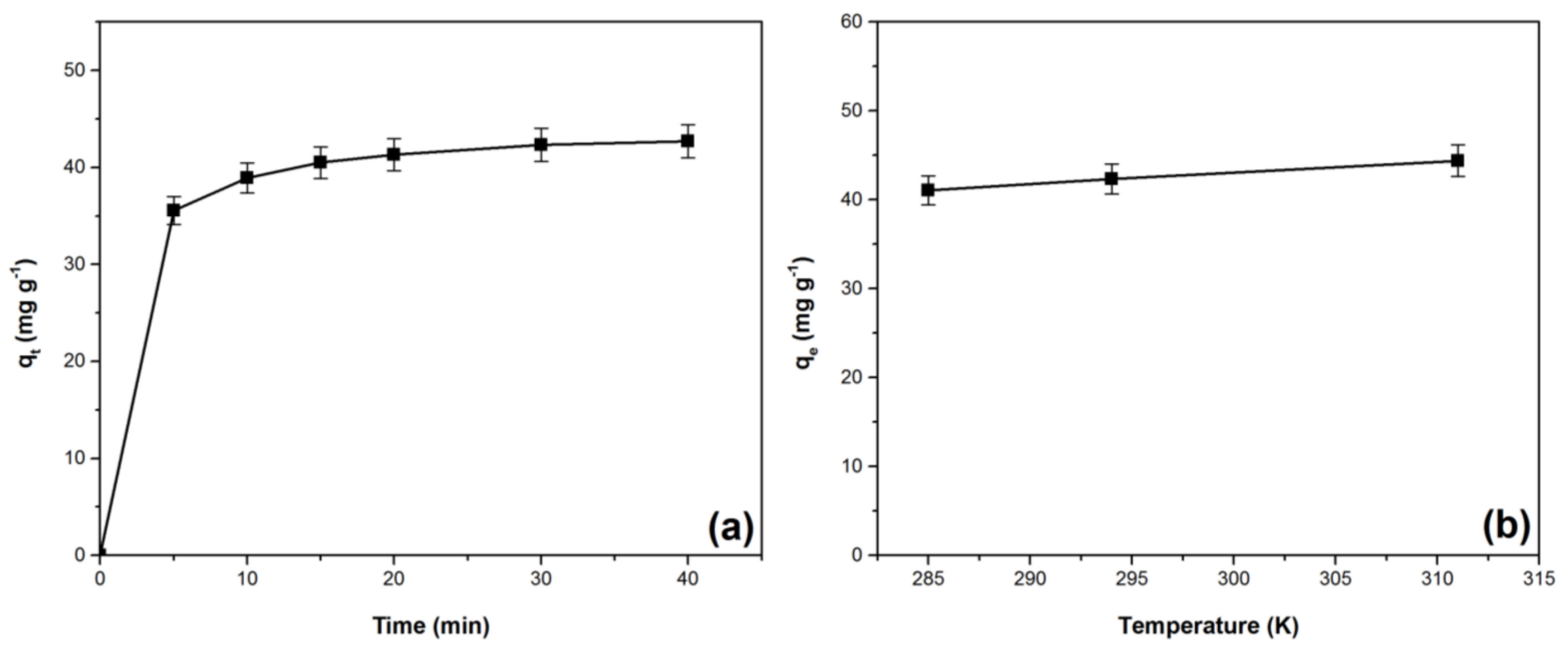

Figure 5. Effect of (a) contact time and (b) temperature on adsorption capacity for the crystal violet adsorption onto Bathurst burr powder [adsorption conditions: (a): $\mathrm{pH} 7$; initial dye concentration: $100 \mathrm{mg} \cdot \mathrm{L}^{-1}$; adsorbent dose: $2 \mathrm{~g} \cdot \mathrm{L}^{-1}$; temperature: $294 \mathrm{~K}$, ionic strength: $0 \mathrm{~mol} \mathrm{~L}{ }^{-1}(\mathbf{b}): \mathrm{pH}$ 7, initial dye concentration: $100 \mathrm{mg} \cdot \mathrm{L}^{-1}$; contact time: $30 \mathrm{~min}$; adsorbent dose: $2 \mathrm{~g} \cdot \mathrm{L}^{-1}$; ionic strength: $\left.0 \mathrm{~mol} \mathrm{~L}^{-1}\right]$. 
The equilibrium times, reported in scientific literature, for different crystal violet adsorbents, were: $15 \mathrm{~min}$ for pecan pericarp [3]; $30 \mathrm{~min}$ for Artocarpus odoratissimus leafbased cellulose [43] and graphene oxide intercalated montmorillonite nanocomposite [60]; $45 \mathrm{~min}$ for functionalized multi-walled carbon nanotubes [50]; $60 \mathrm{~min}$ for Moringa oleifera pod husk [24]; $90 \mathrm{~min}$ for $\mathrm{NaOH}$-modified rice husk [45]; $120 \mathrm{~min}$ for Ocotea puberula bark powder [5], Terminalia arjuna sawdust [9], and pinus bark powder [14]; $150 \mathrm{~min}$ for yeast-treated peat [44]; $180 \mathrm{~min}$ for Eragrostis plana nees [7]; $240 \mathrm{~min}$ for lemongrass leaf combined with cellulose acetate [42]; and $420 \mathrm{~min}$ for crosslinked grafted xanthan gum [48].

The pseudo-first-order and pseudo-second-order models, in the form of non-linear equations $[7,8,43,55-57]$ were employed to study the adsorption kinetics:

$$
\begin{aligned}
& \text { Pseudo - first }- \text { ordermodelequation }: q_{t}=q_{e}\left(1-\exp ^{-k_{1} \cdot t}\right), \\
& \text { Pseudo - second - ordermodelequation }: q_{t}=\frac{k_{2} \cdot t \cdot q_{e}^{2}}{1+k_{2} \cdot t \cdot q_{e}},
\end{aligned}
$$

where: $q_{t}$ is the crystal violet amount adsorbed at time $t\left(\mathrm{mg} \cdot \mathrm{g}^{-1}\right)$, and $k_{1}$ and $k_{2}$ are the rate constants of pseudo-first-order kinetic model and the pseudo-second-order kinetic model, respectively.

Both kinetic model curves for crystal violet adsorption are presented in the Supplementary Material, Figure S3.

The pseudo-second-order kinetic model had the highest value for the determination coefficient $\left(R^{2}\right)$ and the lowest values for sum of square error (SSE), chi-square $\left(\chi^{2}\right)$, and average relative error (ARE), (Table 5). Therefore, this model is the most suitable to characterize the process. A similar observation has been reported in other previous scientific articles $[7,11,14,16,18,19,25]$.

Table 5. Kinetic model constants and the corresponding error functions.

\begin{tabular}{ccc}
\hline Kinetic Model & Parameters & Value \\
\hline & $\mathrm{k}_{1}\left(\mathrm{~min}^{-1}\right)$ & $0.371 \pm 0.021$ \\
Pseudo-first order non-linear & $\mathrm{q}_{\mathrm{e}, \mathrm{calc}}\left(\mathrm{mg}^{-1}\right)$ & $41.40 \pm 0.62$ \\
& $\mathrm{R}^{2}$ & 0.9960 \\
& $\chi^{2}$ & 0.138 \\
& $\mathrm{SSE}$ & 5.56 \\
Pseudo-second order & $\mathrm{ARE}(\%)$ & 16.09 \\
non-linear & $\mathrm{k}_{2}\left(\mathrm{~min}^{-1}\right)$ & $0.019 \pm 0.008$ \\
& $\mathrm{q}_{\mathrm{e}, \mathrm{calc}}\left(\mathrm{mg}^{-1} \mathrm{~g}^{-1}\right)$ & $43.85 \pm 0.21$ \\
& $\mathrm{R}^{2}$ & 0.9999 \\
& $\chi^{2}$ & 0.007 \\
& $\mathrm{SSE}$ & 0.14 \\
& $\mathrm{ARE}(\%)$ & 14.59 \\
\hline
\end{tabular}

Figure $5 b$ illustrates the effect of temperature on the adsorption capacity, indicating that the adsorption process is endothermic in nature [61,62]. A similar aspect has been reported in other previous studies regarding crystal violet absorption [44,54]. The increase of the adsorption capacity can be explained based on the increasing mobility of the dye molecules due to the viscosity decrease with temperature $[44,47,54,62]$.

Standard Gibbs free energy change, standard enthalpy change, and standard entropy change were calculated from experimental data obtained at temperatures of 285, 294, and $311 \mathrm{~K}$ using the equations described in literature [7,56]:

$$
\begin{gathered}
\Delta G^{0}=-R T \ln K_{L}, \\
\ln K_{L}=\frac{\Delta S^{0}}{R}-\frac{\Delta H^{0}}{R T},
\end{gathered}
$$


where: $R$ is the universal gas constant, $K_{L}$ is the Langmuir constant, and $T$ is the absolute temperature.

Thermodynamic parameters (Table 6) were determined from the slope and the intercept of $\ln \mathrm{K}_{\mathrm{L}}$ versus 1/T plot (see Supplementary Material, Figure S4). The data analysis show that the adsorption process is endothermic, spontaneous, and favorable $\left(\Delta \mathrm{H}^{0}>0\right.$, $\left.\Delta G^{0}<0\right)$. The affinity of adsorbent for crystal violet and the increased randomness at the solid-solute interface (the degrees of freedom of the adsorbed species) are indicated by the positive value of $\Delta S^{0}[1,25,56]$. Similar results were obtained by other researchers on low-cost adsorbent materials $[7,14,25]$. The physisorption is involved in the process $\left(\Delta \mathrm{H}^{0}<40 \mathrm{~kJ} \mathrm{~mol}^{-1}\right)[25,44]$ and van der Waals interaction plays an important role in the physical adsorption $\left(\Delta \mathrm{H}^{0}<20 \mathrm{~kJ} \mathrm{~mol}^{-1}\right)$ [63]. When standard Gibbs free energy change $\left(\Delta \mathrm{G}^{0}\right)$ ranges from -20 to $-80\left(\mathrm{~kJ} \mathrm{~mol}^{-1}\right)$ the process is physisorption, intensified by the chemical effect [49].

Table 6. Thermodynamic parameters for the crystal violet adsorption onto Bathurst burr powder.

\begin{tabular}{|c|c|c|c|c|}
\hline \multicolumn{3}{|c|}{$\Delta \mathrm{G}\left(\mathrm{kJ} \cdot \mathrm{mol}^{-1}\right)$} & \multirow[t]{2}{*}{$\Delta \mathrm{H}\left(\mathrm{kJ} \cdot \mathrm{mol}^{-1}\right)$} & \multirow[t]{2}{*}{$\Delta S\left(\mathrm{~J} \mathrm{~mol}^{-1} \cdot \mathrm{K}^{-1}\right)$} \\
\hline $285 \mathrm{~K}$ & $294 \mathrm{~K}$ & $311 \mathrm{~K}$ & & \\
\hline-21.62 & -22.51 & -24.35 & 1.01 & 12.66 \\
\hline
\end{tabular}

\subsection{Optimization Parameters of Adsorption Process Using Taguchi Approach}

The Taguchi method was used to determine the optimal experimental conditions for obtaining the highest efficiency of dye removal from water, using a minimized number of experiments. According to this method, the experimental results are converted into a signal-to-noise $(\mathrm{S} / \mathrm{N})$ ratio, which is an indicator that describes at the same time the level of dispersion and degree of optimization, in relation to the desired value. Depending on the number of controllable parameters and their levels, the Taguchi method uses the proper and most representative orthogonal array that distributes the variables in a balanced way [30-32]. For six controllable factors at three levels, the classical full factorial design must use more experiments $\left(3^{6}=729\right)$ to establish optimal conditions. In this case, the proper Taguchi orthogonal array is $L_{27}$, which reduce the number of experiments to 27 .

The obtained results for dye removal efficiency and the $\mathrm{S} / \mathrm{N}$ ratios for each run are presented in Supplementary Material, Table S1. The S/N ratio rank was used to establish the order of the controllable factors' significance (Table 7). The factor that had the least influence on the process was the temperature, while the factor with the greatest influence was the $\mathrm{pH}$. The optimal conditions to obtain the highest efficiency of crystal violet removal are highlighted in Table 7 . ANOVA results for signal-to-noise $\mathrm{S} / \mathrm{N}$ ratios certify the same order of influence for the controllable factor. The percentage contribution of each factor is shown in Table 7 . The predicted crystal violet removal efficiency was correlated with the experimentally determined one, and it was found that the accuracy of the prediction of the Taguchi method is very good, $\mathrm{R}^{2}$ being close to unity (Figure 6).

Table 7. Response table for signal-to-noise S/N ratios (larger is better) and contribution percentage of controllable factor influence on crystal violet removal process.

\begin{tabular}{|c|c|c|c|c|c|c|}
\hline Level & $\mathrm{pH}$ & Ionic Strength & $\begin{array}{l}\text { Adsorbent } \\
\text { Dose }\end{array}$ & $\begin{array}{l}\text { Initial Dye } \\
\text { Concentration }\end{array}$ & Time & Temperature \\
\hline 1 & 27.40 & $33.76 *$ & 29.14 & $32.97 *$ & 31.75 & 32.40 \\
\hline 2 & 35.04 & 32.36 & 34.34 & 32.96 & 33.05 & 32.66 \\
\hline 3 & $35.70 *$ & 32.01 & $34.65 *$ & 32.19 & 33.33 * & $33.07 *$ \\
\hline Delta & 8.30 & 1.74 & 5.50 & 0.78 & 1.59 & 0.68 \\
\hline Rank & 1 & 3 & 2 & 5 & 4 & 6 \\
\hline Contribution (\%) & 65.00 & 2.60 & 29.23 & 0.62 & 2.19 & 0.36 \\
\hline
\end{tabular}

* The maximum mean $\mathrm{S} / \mathrm{N}$ ratio indicative of optimum condition. 


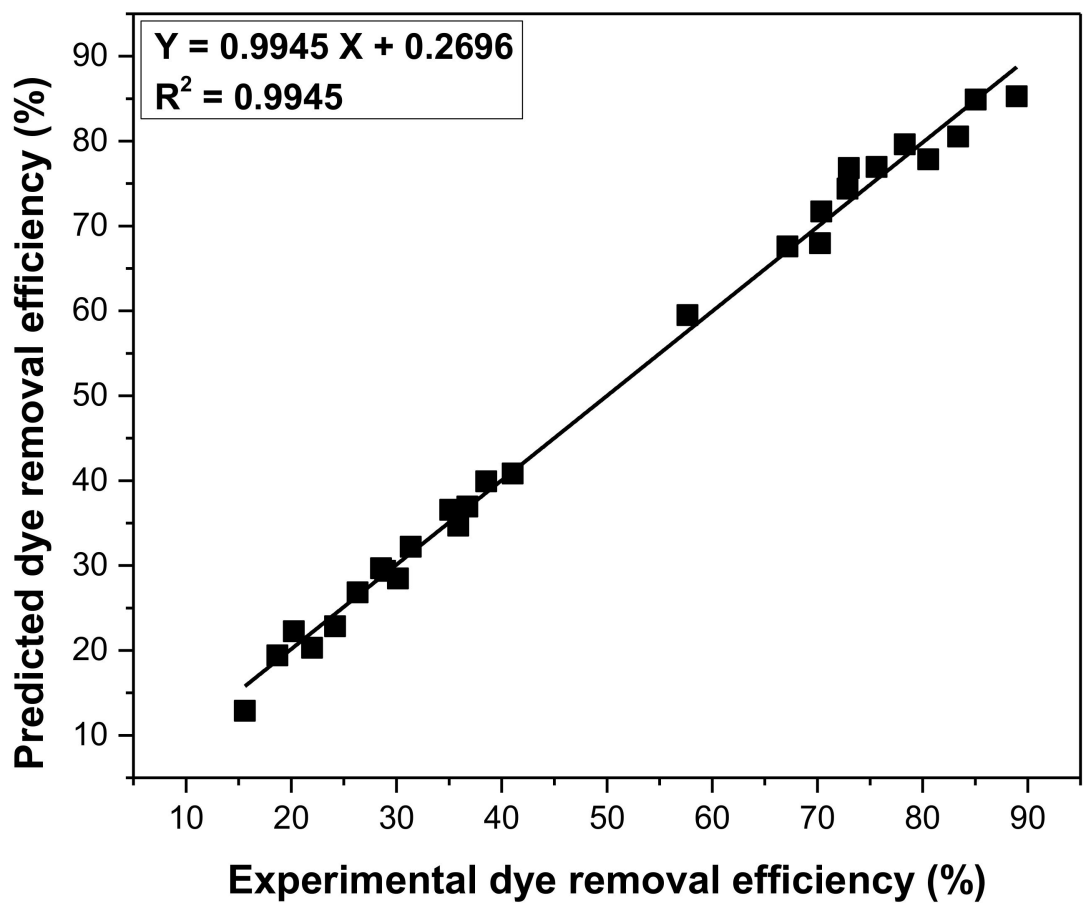

Figure 6. Comparison of experimental and predicted dye removal efficiency.

\subsection{Desorption Study}

The regeneration possibility of the used adsorbent was performed using three desorbing agents $(0.1 \mathrm{M} \mathrm{HCl}$, distilled water, and $0.1 \mathrm{M} \mathrm{NaOH}) . \mathrm{HCl}$ was found as the best desorption agent (see Supplementary Information, Figure S5) but the value of desorption efficiency was lower than $40 \%$. Based on these results and taking into account that Bathurst burr powder is a cheap and easily available material and that desorption involves costs associated with the desorption reagents, it can be concluded that regeneration is not recommended.

The saturated adsorbent, based on its combustion properties as a vegetable material, can be used for direct combustion in specialized incinerators. Another new alternative is to use it as foaming agent for porous glass and ceramic materials based on the gases that result during the thermal synthesis process.

\section{Conclusions}

The natural adsorbent material, Bathurst burr powder, can be successfully used for crystal violet dye removal from aqueous solution. The removal efficiency and the adsorption capacity of this material are influenced by $\mathrm{pH}$, contact time, initial dye concentration, adsorbent dose, and ionic strength. The adsorption process was found to follow Langmuir isotherm and pseudo-second order kinetic model. Maximum adsorption capacity value was higher compared to many similar adsorbents reported in the literature. The adsorption process is endothermic, spontaneous, and favorable. A physisorption mechanism, intensified by the chemical effect, is involved, and the van der Waals interaction plays an important role in the physical adsorption. The Taguchi method shows that the most influential controllable factor was the $\mathrm{pH}$, while the least influential controllable factor was the initial dye concentration. The correlation between the predicted and the experimentally determined dye removal efficiency indicates a very good accuracy of the Taguchi experimental design. 
Supplementary Materials: The following are available online at https:/ / www.mdpi.com/article/10 $.3390 / \mathrm{ma14195861/s1,} \mathrm{Table} \mathrm{S1:} \mathrm{Experimental} \mathrm{layout} \mathrm{of} \mathrm{L27} \mathrm{orthogonal} \mathrm{array} \mathrm{and} \mathrm{results} \mathrm{obtained}$ for removal efficiency and S/N ratios, Figure S1: The particle size distribution of the Bathurst burr powder, Figure S2: Langmuir and Freundlich adsorption isotherms (non-linear forms) for the crystal violet adsorption onto Bathurst burr powder, Figure S3: Pseudo-first-order and pseudo-secondorder kinetic models (non-linear forms) for the crystal violet adsorption onto Bathurst burr powder, Figure S4: Plot of $\ln \mathrm{K}_{\mathrm{L}}$ vs. 1/T for the crystal violet adsorption onto Bathurst burr powder, Figure S5: The desorption efficiencies of crystal violet dye in different media.

Author Contributions: Conceptualization, G.M., C.V. and S.P.; methodology, G.M.; software, G.M. and C.V.; validation, G.M.; formal analysis, G.M., C.V. and S.P.; investigation, G.M., S.P. and S.B.; resources, G.M.; data curation, G.M.; writing-original draft preparation, G.M., C.V., S.P. and S.B.; writing-review and editing, G.M., C.V. and S.P.; visualization, G.M.; supervision, G.M. All authors have read and agreed to the published version of the manuscript.

Funding: This research received no external funding.

Institutional Review Board Statement: Not applicable.

Informed Consent Statement: Not applicable.

Data Availability Statement: All the experimental data obtained are presented, in the form of table and/or figure, in the article and in the Supplementary materials.

Acknowledgments: Not applicable.

Conflicts of Interest: The authors declare no conflict of interest.

\section{References}

1. Aysu, T.; Küçük, M.M. Removal of crystal violet and methylene blue from aqueous solutions by activated carbon prepared from Ferula orientalis. Int. J. Environ. Sci. Technol. 2014, 12, 2273-2284. [CrossRef]

2. Chahinez, H.-O.; Abdelkader, O.; Leila, Y.; Tran, H.N. One-stage preparation of palm petiole-derived biochar: Characterization and application for adsorption of crystal violet dye in water. Environ. Technol. Innov. 2020, 19, 100872. [CrossRef]

3. Franco, D.S.P.; Fagundes, J.L.S.; Georgin, J.; Salaua, N.P.G.; Dotto, G.L. A mass transfer study considering intraparticle diffu-sion and axial dispersion for fixed-bed adsorption of crystal violet on pecan pericarp (Carya illinoensis). Chem. Eng. J. 2020, 397, 125423. [CrossRef]

4. Chowdhury, S.; Chakraborty, S.; Das, P. Removal of Crystal Violet from Aqueous Solution by Adsorption onto Eggshells: Equilibrium, Kinetics, Thermodynamics and Artificial Neural Network Modeling. Waste Biomass- Valorization 2012, 4, 655-664. [CrossRef]

5. Georgin, J.; Franco, D.S.P.; Netto, M.S.; Allasia, D.; Oliveira, M.L.S.; Dotto, G.L. Evaluation of Ocotea puberula bark powder (OPBP) as an effective adsorbent to uptake crystal violet from colored effluents: Alternative kinetic approaches. Environ. Sci. Pollut. Res. 2020, 27, 25727-25739. [CrossRef]

6. Rosly, N.Z.; Abdullah, A.H.; Kamarudin, M.A.; Ashari, S.E.; Ahmad, S.A.A. Adsorption of Methylene Blue Dye by Calix[6]AreneModified Lead Sulphide (Pbs): Optimisation Using Response Surface Methodology. Int. J. Environ. Res. Public Health 2021, $18,397$. [CrossRef]

7. Filho, A.C.D.; Mazzocato, A.C.; Dotto, G.L.; Thue, P.S.; Pavan, F.A. Eragrostis plana Nees as a novel eco-friendly adsorbent for removal of crystal violet from aqueous solutions. Environ. Sci. Pollut. Res. 2017, 24, 19909-19919. [CrossRef]

8. Lim, L.B.L.; Priyantha, N.; Mansor, N.H.M. Artocarpus altilis (breadfruit) skin as a potential low-cost biosorbent for the removal of crystal violet dye: Equilibrium, thermodynamics and kinetics studies. Environ. Earth Sci. 2014, 73, 3239-3247. [CrossRef]

9. Shakoor, S.; Nasar, A. Adsorptive decontamination of synthetic wastewater containing crystal violet dye by employing Ter-minalia arjuna sawdust waste. Groundw. Sustain Dev. 2018, 7, 30-38. [CrossRef]

10. Shoukat, S.; Bhatti, H.N.; Iqbal, M.; Noreen, S. Mango stone biocomposite preparation and application for crystal violet ad-sorption: A mechanistic study. Micropor Mesopor Mater. 2017, 239, 180-189. [CrossRef]

11. Zamouche, M.; Habib, A.; Saaidia, K.; Lehocine, M.B. Batch mode for adsorption of crystal violet by cedar cone forest waste. $S N$ Appl. Sci. 2020, 2, 198. [CrossRef]

12. Ali, H.; Muhammad, S.K. Biosorption of Crystal Violet from Water on Leaf Biomass of Calotropis procera. J. Environ. Sci. Technol. 2008, 1, 143-150. [CrossRef]

13. Wang, X.S.; Liu, X.; Wen, L.; Zhou, Y.; Jiang, Y.; Li, Z. Comparison of Basic Dye Crystal Violet Removal from Aqueous Solution by Low-Cost Biosorbents. Sep. Sci. Technol. 2008, 43, 3712-3731. [CrossRef]

14. Ahmad, R. Studies on adsorption of crystal violet dye from aqueous solution onto coniferous pinus bark powder (CPBP). J. Hazard. Mater. 2009, 171, 767-773. [CrossRef] [PubMed] 
15. Parab, H.; Sudersanan, M.; Shenoy, N.; Pathare, T.; Vaze, B. Use of Agro-Industrial Wastes for Removal of Basic Dyes from Aqueous Solutions. CLEAN - Soil, Air, Water 2009, 37, 963-969. [CrossRef]

16. Smitha, T.; Thirumalisamy, S.; Manonmani, S. Equilibrium and Kinetics Study of Adsorption of Crystal Violet onto the Peel of Cucumis sativa Fruit from Aqueous Solution. E-Journal Chem. 2012, 9, 1091-1101. [CrossRef]

17. Das, P.; Chakraborty, S.; Chowdhury, S. Batch and continuous (fixed-bed column) biosorption of crystal violet by Artocarpus heterophyllus (jackfruit) leaf powder. Colloids Surf. B Colloid Surface B 2012, 92, 262-270. [CrossRef]

18. Chakraborty, S.; Chowdhury, S.; Das, P. Insight into biosorption equilibrium, kinetics and thermodynamics of crystal violet onto Ananas comosus (pineapple) leaf powder. Appl. Water Sci. 2012, 2, 135-141. [CrossRef]

19. Pavan, F.A.; Camacho, E.S.; Lima, E.C.; Dotto, G.L.; Branco, V.T.; Dias, S. Formosa papaya seed powder (FPSP): Preparation, characterization and application as an alternative adsorbent for the removal of crystal violet from aqueous phase. J. Environ. Chem. Eng. 2014, 2, 230-238. [CrossRef]

20. Kulkarni, M.R.; Revanth, T.; Acharya, A.; Bhat, P. Removal of Crystal Violet dye from aqueous solution using water hyacinth: Equilibrium, kinetics and thermodynamics study. Resour. Technol. 2017, 3, 71-77. [CrossRef]

21. Georgin, J.; Marques, B.S.; Peres, E.C.; Allasia, D.; Dotto, G.L. Biosorption of cationic dyes by Pará chestnut husk (Bertholletia excelsa). Water Sci. Technol. 2018, 77, 1612-1621. [CrossRef]

22. Ghazali, A.; Shirani, M.; Semnania, A.; Zare-Shahabadic, V.; Nekoeiniad, M. Optimization of crystal violet adsorption onto Date palm leaves as a potent biosorbent from aqueous solutions using response surface methodology and ant colony. J. Environ. Chem. Eng. 2018, 6, 3942-3950. [CrossRef]

23. Muhammad, U.L.; Zango, Z.U.; Kadir, H.A.; Usman, A. Crystal violet removal from aqueous solution using corn stalk bio-sorbent. Sci. World J. 2019, 14, 133-138.

24. Keereerak, A.; Chinpa, W. A potential biosorbent from Moringa oleifera pod husk for crystal violet adsorption: Kinetics, iso-therms, thermodynamic and desorption studies. Sci. Asia. 2020, 46, 186-194. [CrossRef]

25. Loulidi, I.; Boukhlifi, F.; Ouchabi, M.; Amar, A.; Jabri, M.; Kali, A.; Chraibi, S.; Hadey, C.; Aziz, F. Adsorption of Crystal Violet onto an Agricultural Waste Residue: Kinetics, Isotherm, Thermodynamics, and Mechanism of Adsorption. Sci. World, J. 2020, 2020, 1-9. [CrossRef] [PubMed]

26. Holm, L.R.G.; Plucknett, D.L.; Pancho, J.V.; Herberger, J.P. The World's Worst Weeds. Distribution and Biology; Krieger Pub. Co.: Malabar, FL, USA, 1977; p. 610.

27. Raman, G.; Park, K.T.; Kim, J.-H.; Park, S. Characteristics of the completed chloroplast genome sequence of Xanthium spinosum: Comparative analyses, identification of mutational hotspots and phylogenetic implications. BMC Genom. 2020, $21,1-14$. [CrossRef]

28. Global Invasive Species Database (GISD) 2021. Species Profile Xanthium Spinosum. Available online: http://www.iucngisd.org/ gisd/species.php?sc=1347 (accessed on 23 September 2021).

29. Amin, S.; Barkatullah; Khan, H. Pharmacology of Xanthium species. A review. J. Phytopharm. 2016, 5, 126-127. [CrossRef]

30. Fernández-López, J.A.; Angosto, J.M.; Roca, M.J.; Miñarro, M.D. Taguchi design-based enhancement of heavy metals bioremoval by agroindustrial waste biomass from artichoke. Sci. Total. Environ. 2018, 653, 55-63. [CrossRef]

31. Santra, D.; Joarder, R.; Sarkar, M. Taguchi design and equilibrium modeling for fluoride adsorption on cerium loaded cellulose nanocomposite bead. Carbohydr. Polym. 2014, 111, 813-821. [CrossRef]

32. Zolgharnein, J.; Rastgordani, M. Optimization of simultaneous removal of binary mixture of indigo carmine and methyl orange dyes by cobalt hydroxide nano-particles through Taguchi method. J. Mol. Liq. 2018, 262, 405-414. [CrossRef]

33. Senthamaraikannan, P.; Sanjay, M.R.; Bhat, K.S.; Padmaraj, N.H.; Jawaid, M. Characterization of natural cellulosic fiber frombark of Albizia amara. J. Nat. Fibers 2018, 1-8. [CrossRef]

34. Tsuboi, M. Infrared spectrum and crystal structure of cellulose. J. Polym. Sci. 1957, 25, 159-171. [CrossRef]

35. Karimi, S.; Tahir, P.M.; Karimi, A.; Dufresne, A.; Abdulkhani, A. Kenaf bast cellulosic fibers hierarchy: A comprehensive approach from micro to nano. Carbohydr. Polym. 2013, 101, 878-885. [CrossRef] [PubMed]

36. Labbe, N.; Rials, T.G.; Kelley, S.S.; Cheng, Z.M.; Kim, J.Y.; Li, Y. FT-IR imaging and pyrolysis-molecular beam mass spec-trometry: New tools to investigate wood tissues. Wood Sci. Technol. 2005, 39, 61-76. [CrossRef]

37. Liang, C.Y.; Marchessault, R.H. Infrared spectra of crystalline polysaccharides. II.Native celluloses in the region from 640 to $1700 \mathrm{~cm}^{-1}$. J. Polym. Sci. 1959, 39, 269-278. [CrossRef]

38. Pardo, L.M.F.; Córdoba, A.G.; Galán, J.E.L. Characterization of hemicelluloses from leaves and tops of the CC 8475, CC 8592, and V 7151 varieties of sugarcane (Saccharum officinarum L.). DYNA 2019, 86, 98-107. [CrossRef]

39. Kubovský, I.; Kačíková, D.; Kačík, F. Structural Changes of Oak Wood Main Components Caused by Thermal Modification. Polymers 2020, 12, 485. [CrossRef]

40. Boukir, A.; Fellak, S.; Doumenq, P. Structural characterization of Argania spinosa Moroccan wooden artifacts during natural degradation progress using infrared spectroscopy (ATR-FTIR) and X-Ray diffraction (XRD). Heliyon 2019, 5, e02477. [CrossRef]

41. Blázquez, G.; Martín-Lara, M.; Tenorio, G.; Calero, M. Batch biosorption of lead(II) from aqueous solutions by olive tree pruning waste: Equilibrium, kinetics and thermodynamic study. Chem. Eng. J. 2011, 168, 170-177. [CrossRef]

42. Putri, K.N.A.; Keereerak, A.; Chinpa, W. Novel cellulose-based biosorbent from lemongrass leaf combined with cellulose acetate for adsorption of crystal violet. Int. J. Biol. Macromol. 2020, 156, 762-772. [CrossRef] 
43. Zaidi, N.A.H.M.; Lim, L.B.L.; Usman, A. Artocarpus odoratissimus leaf-based cellulose as adsorbent for removal of methyl violet and crystal violet dyes from aqueous solution. Cellulose 2018, 25, 3037-3049. [CrossRef]

44. Zehra, T.; Priyantha, N.; Lim, L.B.L. Removal of crystal violet dye from aqueous solution using yeast-treated peat as adsorbent: Thermodynamics, kinetics, and equilibrium studies. Environ. Earth Sci. 2016, 75, 1-15. [CrossRef]

45. Chakraborty, S.; Chowdhury, S.; Saha, P.D. Adsorption of crystal violet from aqueous solution onto NaOH-modified rice husk. Carbohydr. Polym. 2011, 86, 1533-1541. [CrossRef]

46. Han, X.; Wang, W.; Ma, X. Adsorption characteristics of methylene blue onto low cost biomass material lotus leaf. Chem. Eng. J. 2011, 171, 1-8. [CrossRef]

47. Pang, J.; Fu, F.; Ding, Z.; Lu, J.; Li, N.; Tang, B. Adsorption behaviors of methylene blue from aqueous solution on mesoporous birnessite. J. Taiwan Inst. Chem. Eng. 2017, 77, 168-176. [CrossRef]

48. Abu Elella, M.H.; Sabaa, M.W.; ElHafeez, E.A.; Mohamed, R.R. Crystal violet dye removal using crosslinked grafted xanthan gum. Int. J. Biol. Macromol. 2019, 137, 1086-1101. [CrossRef] [PubMed]

49. Zhai, Q.-Z. Studies of adsorption of crystal violet from aqueous solution by nano mesocellular foam silica: Process equilibrium, kinetic, isotherm, and thermodynamic studies. Water Sci. Technol. 2020, 81. [CrossRef]

50. Sabna, V.; Thampi, S.G.; Chandrakaran, S. Adsorption of crystal violet onto functionalized multi-walled carbon nanotubes: Equilibrium and kinetic studies. Ecotoxicol. Environ. Saf. 2016, 134, 390-397. [CrossRef]

51. Grassi, P.; Reis, C.; Drumm, F.C.; Georgin, J.; Tonato, D.; Escudero, L.B.; Kuhn, R.; Jahn, S.L.; Dotto, G.L. Biosorption of crystal violet dye using inactive biomass of the fungus Diaporthe schini. Water Sci. Technol. 2019, 79, 709-717. [CrossRef]

52. Patil, S.R.; Sutar, S.S.; Jadhav, J.P. Sorption of crystal violet from aqueous solution using live roots of Eichhornia crassipes: Kinetic, isotherm, phyto and cyto-genotoxicity studies. Environ. Technol. Innov. 2020, 18, 100648. [CrossRef]

53. Mitrogiannis, D.; Markou, G.; Çelekli, A.; Bozkurt, H. Biosorption of methylene blue onto Arthrospira platensis biomass: Kinetic, equilibrium and thermodynamic studies. J. Environ. Chem. Eng. 2015, 3, 670-680. [CrossRef]

54. Mohamed, R.R.; Abu Elella, M.H.; Sabaa, M.W.; Saad, G.R. Synthesis of an efficient adsorbent hydrogel based on biodegradable polymers for removing crystal violet dye from aqueous solution. Cellulose 2018, 25, 6513-6529. [CrossRef]

55. Dotto, G.L.; Salau, N.P.G.; Piccin, J.S.; Cadaval, T.R.S.; de Pinto, L.A.A. Adsorption Kinetics in Liquid Phase: Modeling for Discontinuous and Continuous Systems; Springer: Berlin, Germany, 2017; pp. 52-76.

56. Fabryanty, R.; Valencia, C.; Soetaredjo, F.E.; Putro, J.; Santoso, S.P.; Kurniawan, A.; Ju, Y.-H.; Ismadji, S. Removal of crystal violet dye by adsorption using bentonite - alginate composite. J. Environ. Chem. Eng. 2017, 5, 5677-5687. [CrossRef]

57. Piccin, J.S.; Cadaval, T.R.S.; de Pinto, L.A.A.; Dotto, G.L. Adsorption Isotherms in Liquid Phase: Experimental, Modeling and Interpretations; Springer: Berlin, Germany, 2017; pp. 19-51.

58. Hossain, M.A.; al-Hassan, M.T. Kinetic and thermodynamic studies of the adsorption of crystal violet onto used black tea leaves. Orbital: Electron. J. Chem. 2013, 5, 148-156. [CrossRef]

59. Laskar, N.; Kumar, U. Adsorption of Crystal Violet from Wastewater by Modified Bambusa Tulda. KSCE J. Civ. Eng. 2017, 22, 2755-2763. [CrossRef]

60. Puri, C.; Sumana, G. Highly effective adsorption of crystal violet dye from contaminated water using graphene oxide inter-calated montmorillonite nanocomposite. Appl. Clay Sci. 2018, 166, 102-112. [CrossRef]

61. Liu, T.; Li, Y.; Du, Q.; Sun, J.; Jiao, Y.; Yang, G.; Wang, Z.; Xia, Y.; Zhang, W.; Wang, K.; et al. Adsorption of methylene blue from aqueous solution by graphene. Colloids Surfaces B: Biointerfaces 2012, 90, 197-203. [CrossRef]

62. Mahmoud, D.K.; Salleh, M.A.M.; Karim, W.A.W.A.; Idris, A.; Abidin, Z.Z. Batch adsorption of basic dye using acid treated kenaf fibre char: Equilibrium, kinetic and thermodynamic studies. Chem. Eng. J. 2012, 181-182, 449-457. [CrossRef]

63. Jiang, Z.; Hu, D. Molecular mechanism of anionic dyes adsorption on cationized rice husk cellulose from agricultural wastes. J. Mol. Liq. 2018, 276, 105-114. [CrossRef] 